\title{
Ethanolic Extract of Ground Vernonia Amygdalina Stem Exhibited Potent Antibacterial Activity and Improved Hematological Bio-Functional Parameters in Normal and Monosodium Glutamate-Intoxicated Rats
}

\author{
"EGBUONU, ACC; AMADI, RP
}

\author{
Department of Biochemistry, Michael Okpara University of Agriculture Umudike, Nigeria \\ ${ }^{*}$ Corresponding Author Email: tonycemalukegbuonu@yahoo.com; Tel: +2348036366565
}

\begin{abstract}
Herein, Vernonia amygdalina stem ethanolic extract, VASEE, was elucidated for its antibacterial activity in vitro by disk-diffusion technique and, in vivo effect on some hematological parameters of normal and monosodium glutamate, MSG-intoxicated rats. For in vivo study, 20 male albino rats assigned into five groups (A, B, C, $\mathrm{D}$, and E) were, for 14 days, respectively administered MSG ( $8000 \mathrm{mg} / \mathrm{kg}$ body weight, bw), VASEE (200 mg/kg bw), Control (Vital feed and tap water), MSG ( $8000 \mathrm{mg} / \mathrm{kg}$ bw + VASEE, $200 \mathrm{mg} / \mathrm{kg} \mathrm{bw})$, and MSG (8000 mg/kg bw + VASEE, $400 \mathrm{mg} / \mathrm{kg}$ bw). In vitro, the VASEE-related activity against the tested bacterial pathogens was significant $(\mathrm{P}<$ 0.05), dose dependent and comparable to that by the standard antibacterial drug, Ciprofloxacin. In vivo, VASEE compared to control and MSG groups improved $(\mathrm{P}<0.05)$ and, notably at the highest tested dose modulated the monosodium glutamate intoxication-related effect on, the studied hematology of rats. Thus, VASEE exhibited potent activity against the tested bacterial pathogens, improved, and potentially modulated MSG-intoxication-related effect on, the rats' hematological functions. The study underscored a promising antibacterial application of the extract of hitherto wasted bitter leaf stem that could offer novel therapeutic benefits on the hematology of especially MSG-intoxicated rats, warranting further studies.
\end{abstract}

DOI: https://dx.doi.org/10.4314/jasem.v25i3.2

Copyright: Copyright (C) 2021 Egbuonu and Amadi. This is an open access article distributed under the Creative Commons Attribution License (CCL), which permits unrestricted use, distribution, and reproduction in any medium, provided the original work is properly cited.

Dates: Received: 12 December 2020; Revised: 26 January 2021; Accepted: 12 February 2021

Keywords: Hematology, intoxication, bitter leaf stem, packed cell volume, Red blood cell

In Nigeria, bitter leaf (Vernonia amygdalina) stem is not considered edible and is rarely used except for replanting, hence may add to the increasing sources of municipal solid waste. And, as the bitter leaf stem is not readily biodegradable, it could pose waste disposal problem and attendant environmental and health risk (Egbuonu, et al., 2015; Egbuonu, 2015a,b,c,d; Egbuonu and Osuji, 2016; Egbuonu, et al., 2016). Studies to enhance the utilization of such solid waste especially for novel bioactivity against chemical toxicants usually and intentionally added to foods are therefore warranted (Makris, 2007). Vernonia amygdalina, commonly called bitter leaf, is a medium sized shrub grown in the tropics (Achuba, 2018). And, among the Nigerian population it has different common names, including Onugbu (in Igbo). The leaves, that commonly serve as vegetable for traditional soup delicacy, are with bioactivities useful in ethno-medication against varied ailments including malaria, diabetes, cancer, infertility and ailments related to microbes and impaired hematological properties owing to a variety of flavonoid and bitter sesquiterpene lactones contents (Kadir, et al., 2018; Achuba, 2018). Monosodium glutamate (MSG) is a common food addictive but with safety issues (Wijayasekara and Wansapala, 2017; Zeratsky, 2020; Veni, 2010). And, it could be abused inadvertently warranting the need for antidotes, including any readily available indigenous plant-part-waste-sourced material. Recent studies indicated possibility of plants and plant-parts-based antidotes for chemical toxicity in animals (Achuba, 2018; Okpoghono, et al., 2018), scientific basis for ethno-medicinal uses (Egbuonu, 2015) and even improved keeping quality of plantsbased antidotes (Egbuonu, et al., 2014a; Egbuonu, et al., 2014b). Earlier, extract of Vernonia amygdalina leaf elicited antibacterial activity against many pathogens (Cos et al., 2002) and increased packed cell volume, neutrophil and white blood cells count with consequent hemolytic reduction (Kola, 2007; Kadir, et al., 2018). Also, several research reports established the safety of bitter leaf administration either alone or together with known toxicants (Kadiri, 2017; Abebe and Gebru, 2015; Lolodi and Eriyamremu, 2013). However, antibacterial activity of Vernonia amygdalina stem extract or its influence on the hematology of MSG-burdened animals, to the authors' knowledge, has not been reported. Dietary 
intervention even from hitherto plant part waste including the Vernonia amygdalina stem could be relevant source for toxic chemical antidote (Ezeanyika and Egbuonu, 2011). Hence, the present study was undertaken with the aim to determine the antibacterial activity of bitter leaf (Vernonia amygdalina) stem extract and the effect of the stem extract on some hematological parameters of normal and monosodium glutamate-intoxicated rats. The objectives for achieving the stated study aim included determination of the (a) activity (expressed as the mean diameter of inhibition zones, $\mathrm{mm}$ ) of ground Vernonia amygdalina stem ethanolic extract, VASEE, on Escherica coli (E. coli), Neisseria gonorrhoeae (N. gonorrhoeae), Staphylococcus aureus (S. aureus), Pseudomonas aeroginosa (P. aeroginosa), Salmonella typhi ( $S$. typhi) and Streptococcus pneumonia (S. pneumonia pathogens and (b) effect of ground Vernonia amygdalina stem extract, VASEE on packed cell volume (PCV), hemoglobin (HB) and red blood cell (RBC) contents of normal and monosodium glutamate-intoxicated rats. In a recent similar study, bitter leaf stem extract exhibited potent antifungal activity without altering serum electrolytes in MSGintoxicated rats' (Nwankwo, et al., 2019). In particular, changes in hematological properties highly predicted animal toxicity (Chike, et al., 2018) and hematological parameters, including red blood cells (RBC) count, hemoglobin (HB) concentration and packed cell volume (PCV), determined herein served as important indices of physiological and pathological status in animal studies (Iwueke, et al., 2018; Egbuonu, et al., 2019).

\section{MATERIALS AND METHODS}

Materials: Monosodium glutamate, MSG, (99.9 \%) was purchased from Ubani foodstuff market in Umuahia, Abia state. Nigeria. All the chemicals, including absolute ethanol (99\%), picric acid and chloroform, used were of analytical grade and products of Sigma Aldrich, St. Louis, USA.

Fresh stems of bitter leaf (Vernonia amygdalina) were collected in the month of May, 2015 from locals in Ikwuano Local Government Area, Abia state, Nigeria and authenticated as that of biter leaf (Vernonia amygdalina) by a Taxonomist in the Department of Plant Science and Biotechnology, College of Natural Sciences, Michael Okpara University of Agriculture, Umudike.

A total of 20 adult male Wistar rats which weighed between $120 \mathrm{~g}-160 \mathrm{~g}$ were procured from the animal house of the Department of Zoology, University of Nigeria, Nsukka. The animals were harbored in the animal housing unit of the Department of
Biochemistry, College of Natural Sciences, Michael Okpara University of Agriculture, Umudike, in clean metabolic cages at room temperature and under standard laboratory condition of 12 hour light/dark cycle. The rats had free access to pellet feed (Vital Feed) and clean tap water during acclimatization for two weeks.

Methodology: The bitter leaf stems were rinsed with clean water, cut into smaller pieces and air dried for a period of one week. The dried stems were ground using a pulverizing machine in the Department of Soil Science, National Root Crops Research Institute, Umudike. From the obtained ground bitter leaf stem, $400 \mathrm{~g}$ of the powder was soaked in $300 \mathrm{ml}$ of absolute ethanol for a period of 48 hours. The resulting mixture was then filtered using the Whattman's filter paper. The filtrate obtained in a beaker of known weight was placed on a water bath at temperature of $40^{\circ} \mathrm{C}$. After evaporation of the ethanol, approximately $80 \mathrm{~g}$ thick brown semisolid paste of the extract ( $1.5 \mathrm{~g}$ yield) was obtained. Refrigeration of extract was maintained at 2 $-8{ }^{\circ} \mathrm{C}$ until used.

Escherica coli (E. coli), Neisseria gonorrhoeae ( $N$. gonorrhoeae), Staphylococcus aureus (S. aureus), Pseudomonas aeroginosa (P. aeroginosa), Salmonella typhi (S. typhi) and Streptococcus pneumonia ( $S$. pneumonia) used in this study were clinical isolates obtained from the Department of Pharmaceutical Microbiology Laboratory, College of Health Sciences, University of Nigeria teaching Hospital (UNTH) Enugu, Nigeria. They were characterized with respect to their morphological, biochemical and antibiotic susceptibility. Antibacterial activity of different VASEE concentrations in $10 \mathrm{~mm}$ discs was tested by the disk-diffusion technique as in Kigigha and Atuzie (2010). In brief, antibiotic discs $(10 \mathrm{~mm})$ were prepared from Whattman No. 1 filter paper using cock borer and autoclaved at $0{ }^{\circ} \mathrm{C}$ for sterility. Subsequently, the discs were respectively impregnated with varying concentrations of the VASEE $(125,250$, 500,1000 and $2000 \mathrm{mg} / \mathrm{ml}$ ) or $10 \mathrm{mg} / \mathrm{ml}$ of Ciprofloxacin control, and (in triplicates) placed on well-spaced separate nutrient agar plates to avoid overlapping of the zones of inhibition. The plates were then incubated at $37{ }^{\circ} \mathrm{C}$ for $72 \mathrm{~h}$. The antibacterial activity was expressed as the mean diameter of inhibition zones (mm).

Experimental animal design: After acclimatization, the rats were weighed and randomly assigned to five groups, A,B,C,D and E that respectively received MSG only, the extract, VASEE, only, feed and clean tap water as others, MSG plus low dose $(200 \mathrm{mg} / \mathrm{kg}$ bw) of the extract, VASEE and MSG plus high dose 
(400 mg/kg bw) of the extract, VASEE. Accurately weighed quantity of hydro-alcoholic (98\% ethanol) extract of $V$. amygdalina stem, VASEE, was suspended in distilled water and was administered orally to the experimental animals.

Freshly prepared MSG solution (using distilled water as solvent) was administered orally with the aid of a gavage according to previous studies (Mariyamma, et al., 2009; Egbuonu and oriji, 2017; Egbuonu and Ekwuribe, 2017; Mbah and Egbuonu, 2017a,b; Egbuonu and Ejike, 2017; Mbah, et al., 2018; Mbah, et al., 2019; Anuforo, et al., 2020; Obidike and Egbuonu, 2020). Treatment was by daily intubation and lasted for 14 days. The animal study was carried out following approval from the departmental ethical committee which was in strict adherence to the National research council guide for the care and use of laboratory animals (National Research Council, NRC, 2011).

All the rats in the different groups were sacrificed by mild stunning following overnight fast after 14 days. Thereafter, the respective rat was dissected and blood collected from the heart. As described earlier (Egbuonu and Oparah, 2017), the red blood cell count was determined by haemocytometric method which involved diluting 1:200 blood specimen with RBC diluting fluid (Sodium Citrate) and counting the red blood cells under high power $(40 \times)$ objective by using a counting chamber. The number of cells was calculated and reported as the concentration of red blood cells of whole blood $\left(\times 10^{12} / \mathrm{L}\right)$.

The hemoglobin concentration was determined using cyanomethaglobin method as described by Ochei and Kolhatkar (2008). This was based on the principle that hemoglobin when mixed with Drabkin's solution (that contains potassium ferricyanide, potassium cyanide and potassium dihydrogen phosphate) the ferricyanide form methaemoglobin is converted to cyanmethaemoglobin by the cyanide and the cyanmethaemoglobin produces a colour which is measured colorimetrically in $\mathrm{g} / \mathrm{dl}$. The packed cell volume, PCV was estimated as described by Ochei and Kolhatkar (2008). Blood sample was taken with a capillary tube, cleaned and sealed with plasticine. The filled tubes were placed in the microhematocrit centrifuge, spun at 12,000 rotor per minute (rpm) for 5 minutes and placed in a specially designed scale. PCV (\%) was read as percentage content in a whole blood using a hematocrit reader (Hawskey, England) and as calculated thus:

$$
\text { PCV }(\%)=\frac{\text { Packed RBC column height }}{\text { Total blood volume height }} \times 100
$$

Where $\mathrm{PVC}=$ packed cell volume,

Statistical analysis: Data were subjected to analysis of variance (ANOVA) and least significance difference (LSD) at $95 \%$ confidence level using statistical package for social sciences, SPSS, statistical software package, version 20. Mean results for triplicate determinations of bacterial activity, and animal sample size, $n=4$ rats were expressed as Mean \pm Standard error of mean (SEM). Difference in mean was accepted as statistically significant at $\mathrm{P}<0.05$.

\section{RESULTS AND DISCUSSION}

The extract had a significant $(\mathrm{P}<0.05)$ and dose dependent activity against the tested bacterial pathogens. Maximum activity on all tested organisms was observed at $2000 \mathrm{mg} / \mathrm{ml}$ and was comparable to the respective activity elicited by the standard antibacterial drug, Ciprofloxacin (Table 1, Figure 1 and Figure 2). Results of earlier antibacterial studies of $V$. amygdalina leaf showed variable degree of antibacterial activities (Ali, et al., 2019).

The result of this study conformed to reported earlier studies that ethanol extract of $V$. amygdalina leaf elicited activity against $S$. aureus (Ogundare, 2011; Zubairu, et al., 2019), E. coli and S. typhi (Zubairu, et al., 2019), indicating the potency also of $V$. amygdalina stem against these pathogens. The present result, however, contradicted that of Ogundare (2011) who reported inactivity of $V$. amygdalina leaf extract against $E$. coli, indicating selective potency of $V$. amygdalina stem over $V$. amygdalina leaf against $E$. coli (and apparent preference of $V$. amygdalina stem over the leaf in managing E. coli-related ailments).

Table 1: Activity (expressed as the mean diameter of inhibition zones, $\mathrm{mm}$ ) of ground Vernonia amygdalina stem ethanolic extract, VASEE, on E. coli, N. gonorrhoeae, S. aureus and P. aeroginosa pathogens

\begin{tabular}{|c|c|c|c|c|c|c|}
\hline Pathogen (mm) & $\begin{array}{l}\text { VASEE } \\
2000 \mathrm{mg} / \mathrm{ml}\end{array}$ & $\begin{array}{l}\text { VASEE } \\
1000 \mathrm{mg} / \mathrm{ml}\end{array}$ & $\begin{array}{l}\text { VASEE } \\
500 \mathrm{mg} / \mathrm{ml}\end{array}$ & $\begin{array}{l}\text { VASEE } \\
250 \mathrm{mg} / \mathrm{ml}\end{array}$ & $\begin{array}{l}\text { VASEE } \\
125 \mathrm{mg} / \mathrm{ml}\end{array}$ & $\begin{array}{l}\text { Ciplofloxacin } \\
10 \mathrm{mg} / \mathrm{ml}\end{array}$ \\
\hline $\begin{array}{l}\text { E. coli } \\
\text { N. gonorrhoeae } \\
\text { S. aureus } \\
\text { P. aeroginosa }\end{array}$ & $\begin{array}{l}50.33 \pm 0.88 \\
48.00 \pm 1.15 \\
45.00 \pm 0.58 \\
31.67 \pm 0.88\end{array}$ & $\begin{array}{l}24.00 \pm 0.58 \\
23.00 \pm 0.58 \\
21.00 \pm 0.58 \\
16.00 \pm 0.58\end{array}$ & $\begin{array}{l}11.00 \pm 0.58 \\
11.00 \pm 0.58 \\
10.67 \pm 0.33 \\
8.00 \pm 0.58\end{array}$ & $\begin{array}{l}5.33 \pm 0.33 \\
4.00 \pm 0.58 \\
4.00 \pm 0.58 \\
2.67 \pm 0.33\end{array}$ & $\begin{array}{l}1.00 \pm 0.58 \\
0.67 \pm 0.67 \\
0.33 \pm 0.33 \\
1.33 \pm 0.33\end{array}$ & $\begin{array}{l}68.00 \pm 1.15 \\
64.67 \pm 0.88 \\
54.00 \pm 1.15 \\
37.33 \pm 0.88\end{array}$ \\
\hline
\end{tabular}




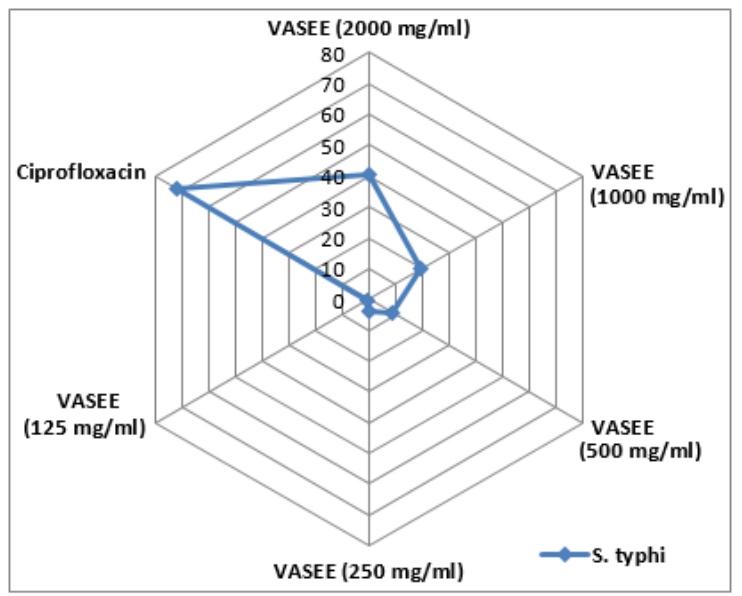

Fig 1: Activity $(\mathrm{mm})$ of ground Vernonia amygdalina stem ethanolic extract, VASEE, on S. typhi pathogen. Result Values are expressed as Mean for sample size, $n=4$ rats. Significant difference in mean was accepted at $P<0.05$

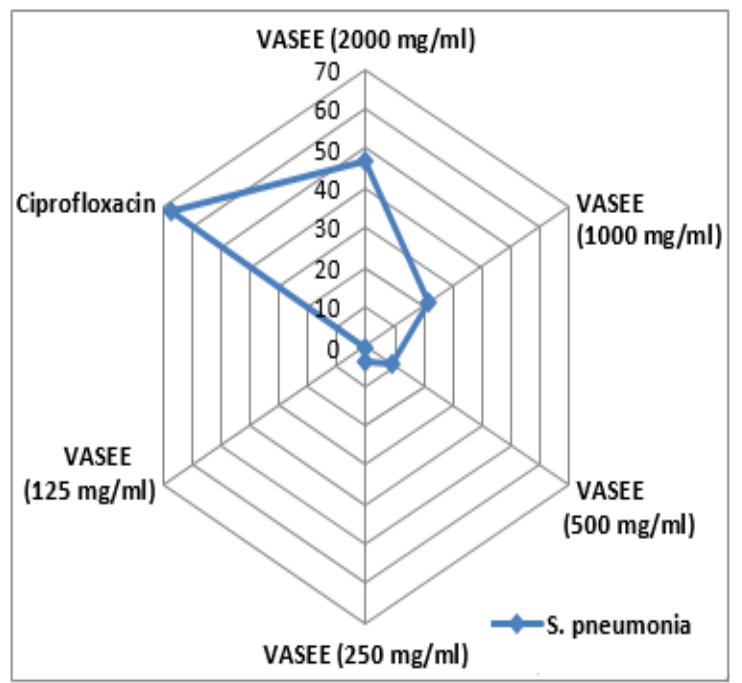

Fig 2: Activity $(\mathrm{mm})$ of ground Vernonia amygdalina stem ethanolic extract, VASEE, on S. pneumonia pathogen. Result Values are expressed as Mean for sample size, $\mathrm{n}=4$ rats. Significant difference in mean was accepted at $\mathrm{P}<0.05$
Thus VASEE exhibited potent activity against the tested bacterial pathogens which comprises Grampositive and Gram-negative bacteria, suggesting that $V$. amygdalina stem extract (VASEE) could be beneficial if incorporated in the development of novel herbal formulation for preventing broad spectrum bacterial infections (Ali, et al., 2019). Furthermore, in vivo the extract (at $200 \mathrm{mg} / \mathrm{kg} \mathrm{bw}$ ) as compared to the control and MSG groups improved $(\mathrm{P}<0.05)$ and, notably at the highest tested dose modulated the monosodium glutamate intoxication-related effect on, the studied hematological parameters of rats (Table 2). Results of earlier antibacterial studies of $V$. amygdalina leaf showed variable degree of antibacterial activities (Ali, et al., 2019). The result of this study conformed to reported earlier studies that ethanol extract of $V$. amygdalina leaf elicited activity against S. aureus (Ogundare, 2011; Zubairu, et al., 2019), E. coli and S. typhi (Zubairu, et al., 2019), indicating the potency also of $V$. amygdalina stem against these pathogens. The present result, however, contradicted that of Ogundare (2011) who reported inactivity of $V$. amygdalina leaf extract against $E$. coli, indicating selective potency of $V$. amygdalina stem over $V$. amygdalina leaf against $E$. coli (and apparent preference of $V$. amygdalina stem over the leaf in managing $E$. coli-related ailments). Thus VASEE exhibited potent activity against the tested bacterial pathogens which comprises Gram-positive and Gramnegative bacteria, suggesting that $V$. amygdalina stem extract (VASEE) could be beneficial if incorporated in the development of novel herbal formulation for preventing broad spectrum bacterial infections (Ali, et al., 2019). Furthermore, in vivo the extract (at 200 $\mathrm{mg} / \mathrm{kg} \mathrm{bw}$ ) as compared to the control and MSG groups improved $(\mathrm{P}<0.05)$ and, notably at the highest tested dose modulated the monosodium glutamate intoxication-related effect on, the studied hematological parameters of rats (Table 2).

Table 2. Effect of ground Vernonia amygdalina stem extract, VASEE on packed cell volume (PCV), hemoglobin (HB) and red blood cell (RBC) contents of normal and monosodium glutamate-intoxicated rats

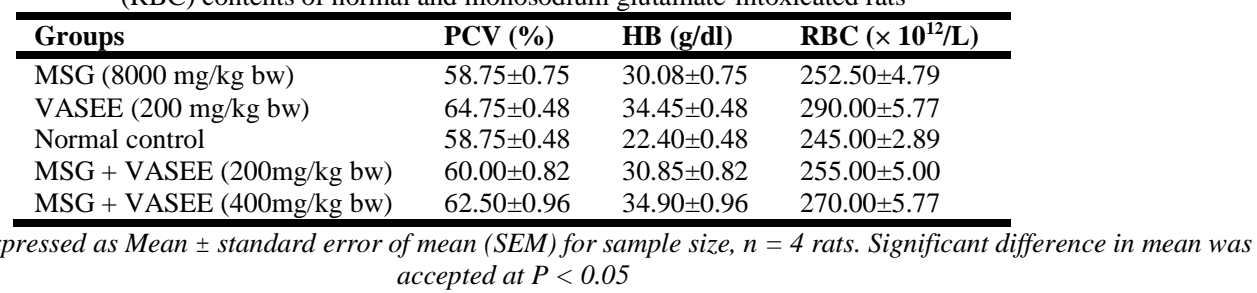

Red blood cell and hemoglobin function in the efficient transport of oxygen into and carbon dioxide out of, the body and in concert with PCV (the percentage of RBC in blood) indicates oxygen carbon dioxide balance status (Egbuonu, et al., 2019;
Oyedeji and Bolarinwa, 2013; Ugwuene, 2011). Furthermore, although non-significant influence on rats' hemoglobin and RBC levels but slight reduction in packed cell volume (PCV) concentration, were interpreted as absence of adverse effect on the rats' 
hematological properties (Iwueke, et al., 2018); Agiang, et al. (2017) associated possession of some anti-anemic properties following improved/elevated $\mathrm{RBC}, \mathrm{Hb}$ and PCV. Thus, the significant elevation in the levels of RBC, HB and PCV of the rats following exposure to bitter leaf stem extract as reported herein could be indicating improved gaseous (oxygen and carbon dioxide) transport leading to favorable oxygen - carbon dioxide balance, and improved anti-anemic properties in the rats. This may further suggest that $V$. amygdalina stem extract could confer overall nonadversity and could potentially modulate MSGintoxication-related effect, on the rats' hematological functions. The study therefore underscored a promising application of the extract of hitherto wasted bitter leaf stem in novel drug development that could offer novel therapeutic benefits on the hematology of especially MSG-intoxicated rats, warranting further studies.

Conclusion: The crude extract of bitter leaf stem, VASEE exhibited potent activity against the tested bacterial pathogens, improved, and potentially modulated MSG-intoxication-related effect on, the rats' hematological functions. The study underscored a promising antibacterial application of the extract of hitherto wasted bitter leaf stem that could offer novel therapeutic benefits on the hematology of especially MSG-intoxicated rats. Furthermore, the study could be a stepping stone to potential novel drug development, warranting further studies.

\section{REFERENCES}

Abebe, MS; Gebru, G (2015). Toxic effect of Vernonia amygdalina Delile on blood parameters and histopathology of liver and kidney in rats. Global Med. Plants Res. 1: 001-008

Achuba, FI (2018). Role of bitter leaf (Vernonia amygdalina) extract in prevention of renal toxicity induced by crude petroleum contaminated diets in rats. Int. J. Vet. Sci. Med. 6: 172-177

Agiang, MA; Dongo, BS; Williams, IO; Utu-Baku, AB (2017). Assessment of the haematological indices of albino rats fed diets supplemented with jackfruit bulb, seed or a blend of bulb and seed. Int. J. Biol. Chem. Sci. 11(1): 397-407

Ali, M; Diso, SU; Waiya, SA; Abdallah, MS (2019). Phytochemical screening and antibacterial activity of bitter leaf (Vernonia amygdalina). Annals Microbiol. Infectious Dis. 2(4): 01-07

Anuforo, PC; Egbuonu, ACC; Egu, EU (2020). Terminalia catappa flour extract mitigated monosodium glutamate-intoxicated rats' kidney biofunction and histology. The J. Phytopharmacol. 9(3): 164-168

Chike, CPR; Njoku, B; Green, K; Akpojotor, PI; Onyebuenyi, MO; Numbara, D (2018). Effect of ethanolic leaf extract of Vernonia amygdalina (bitter leaf) extract on some of the haematological parameters in Wistar rats. J. Comp. Alt. Med. Res. 5(1): $1-7$

Cos, P; Hermans, N; DeBruyne, T; Apers, Sindambiwe, JB; Berghe DV; Pieter, L; Vlietinck, AJ. (2002). Further evaluation of Rwandan medicinal plant extracts for their anti-microbial and anti-viral activities. J. Ethno-pharmacol. 79: $155-163$

Egbuonu, ACC (2015a). Comparative assessment of some mineral, amino acid and vitamin compositions of watermelon (Citrullus lanatus) rind and seed. Asian J. Biochem. 10(5): 230-236

Egbuonu, ACC (2015b). Assessment of some antinutrient properties of watermelon (Citrullus lanatus) rind and seed. Res. J. Environ. Sci. 9(5): 225-232

Egbuonu, ACC (2015c). Comparative investigation of the antibacterial and antifungal potentials of the extracts of watermelon (Citrullus lanatus) rind and seed. Eur. J. Med. Plants. 9(4): 1-7.

Egbuonu, ACC (2015d). Comparative investigation of the proximate and functional properties of watermelon (Citrullus lanatus) rind and seed. Res. J. Environ. Toxicol. 9(3): 160-167.

Egbuonu, ACC; Aguguesi, RG; Samuel, R; Ojunkwu, O; Onyenmeri, F; Uzuegbu, U (2015). Some physicochemical properties of the petroleum etherextracted watermelon (Citrullus lanatus) seed oil. Asian J. Sci. Res. 8(4): 519-525.

Egbuonu, ACC; Ejike, GE (2017). Effect of pulverized Mangifera indica (mango) seed kernel on monosodium glutamate-intoxicated rats' serum antioxidant capacity, brain function and histology. EC Pharmacol. Toxicol. 4(6): 228-243.

Egbuonu, ACC; Ekwuribe, GA (2017). Pulverized Mangifera indica (mango) seed-kernel modulated serum lipid profile in monosodium glutamatechallenged rats. J. App. Biotechnol. 5(2): 72-87. 
Egbuonu, ACC; Harry, EM; Orji, IA (2016). Comparative proximate and antibacterial properties of milled Carica papaya (pawpaw) peels and seeds. Br. J. Pharm. Res. 12(1): 1-8.

Egbuonu, ACC; Nzewi, DC; Egbuonu, ONC (2014a). Functional properties of bitter yam (Dioscorea dumetorum) as influenced by soaking prior to oven-drying. Am. J. Fd. Technol. 9(2): 97-103.

Egbuonu, ACC; Nzewi, DC; Egbuonu, ONC (2014b). Effect of soaking prior to oven-drying on some nutrient and anti-nutrient properties of bitter yam (Dioscorea dumetorum). J. Nutr. Fd. Sci. 4: 280.

Egbuonu, ACC; Opara, CI 2017. Avocado pear (Persea americana) seed flour 1: Some mineral contents and effect of the ethanolic extract on the hematology of normal and monosodium glutamate-intoxicated rats. J. Fd. Nutr. Pop. Health, JFNPH. 1(3): 23-28.

Egbuonu, ACC; Oriji, SO (2017). Pulverized Mangifera indica (mango) seed kernel mitigated monosodium glutamate-intoxicated rats' kidney histology and bio-functions. J. Nutr. Health Fd. Sci. 5(2): 1-7.

Egbuonu, ACC; Osuji, CA (2016). Proximate compositions and antibacterial activity of Citrus sinensis (sweet orange) peel and seed extracts. Eur. J. Med. Plants. 12(3): 1-7.

Egbuonu, ACC; Uzoma, SC; Uroko, RI; Njoku, JC; Oriaku, CE; Nwankwo, CI (2019). Hematological changes in $\mathrm{L}$-arginine co-treated paracetamolintoxicated Wistar rats. EC Pharmacol. Toxicol. 7(2): 01-07.

Ezeanyika, LUS; Egbuonu, ACC (2011). Impact of nitric oxide and insulin resistance on the pathophysiology of the metabolic syndrome: Possible role of l-arginine and glutamate. J. Med. Med. Sci. 2(2): 657-662.

Iwueke, AV; Ihenacho, K; Nwodu, J (2018). Evaluation of haematological properties of Wistar albino rats fed Curcuma longa (Tumeric) rhizome powder. The Fed. Am. Soc. Exp. Biol. (FASEB) J. 31(S1): 974.5-974.5.

Kadir, RE; Ibrahim, A; Bamtefa, IM; Ibrahim, BA; Ogunfemi, MK; Gwadabe, SM; Jaji-Sulaimon, R; Adigun, FM; Ajao, MS (2018). Haematological effects of aqueous extract of Vernonia amygdalina and a known immunostimulant in Wistar rats. Tropical J. Health Sci. 25(1): 02-09.

Kadiri, HE (2017). Protective effect of Vernonia amygdalina (bitter leaf) extract on rats exposed to cyanide poisoning. Biokemistri. 29: 126-131.

Kigigha, LT; Atuzie, MN (2012). Assessment of traditional medicinal application of Alchornea cordifolia. Afr. J. Biotechnol. 11(8): 2083-2086.

Kola, OM (2007). Anti-inflammatory activity of ethanolic leaf extract from Vernonia amygdalina on the immune system of swiss albino rats dosed with Clostridium sporogenes (NCIB) 532. Res. J. Med. Sci. 1:127-131.

Lolodi, O; Eriyamremu, GE (2013). Effect of methanolic extract of Vernonia amygdalina (Common bitter leaf) on lipid peroxidation and antioxidant enzymes in rats exposed to cycasin. Pak. J. Biol. Sci. 16: 642-646.

Makris, DP; Boskou, G; Andrikopoulos, NK (2007). Recovery of antioxidant phenolics from white vinification solid by-product employing water/ethanol mixtures. Bio-resource Technol. 98(15): 2963-2967.

Mariyamma, T; Sujatha, KS; George, S (2009). Protective effect of Piper longum Linn on monosodium glutamate-induced oxidative stress in rats. Indian J. Exp. Biol. 47(3): 186-192. Mbah, $\mathrm{UO}$;

Egbuonu, ACC (2017a). Ethanolic extract of Solanum melongena Linn fruit mitigated monosodium glutamate-induced oxidative stress. Int. J. Biochem. Res. Rev. 18(2): 1-8:

Mbah, UO; Egbuonu, ACC (2017b). Ameliorative potentials of eggplant (Solanum melongena Linn) fruit ethanolic extract on monosodium glutamateintoxicated rats' lipid profile, haematology and heart histology. Int. J. Biochem. Res. Rev.18 (3): 110 .

Mbah, UO; Egbuonu, ACC; Achi, NK; Nwanne,ID; Jeremiah, O (2019). Hepatoprotective potentials of ethanolic extract of Solanum melongena Linn fruit on monosodium glutamate-intoxicated rats' and liver section histology. Int. Blood Res. Rev. 9(1): 19,

Mbah, UO; Egbuonu, ACC; Omodamiro, OD; Obinna, J; Nwanne, ID (2018). In vitro antioxidant and antimicrobial activity of ethanolic extract of 
eggplant (Solanum melongena Linn) fruit. Asian J. Res. Med. Pharm. Sci. 5(4): 1-10.

National Research Council, NRC 2011. Guide for the care and use of laboratory animals. 8th ed. Institute of Laboratory Animal Research Division on Earth and Lifer Studies, National Academy Press, Washington, DC, USA. Pp 1-246.

Nwankwo, NE; Egbuonu, ACC; Aliuba, PO; Okeke, ES (2019). Antifungal properties of ethanol extract of Vernonia amygdalina stem and the effect on electrolyte status in normal and monosodium glutamate-intoxicated rats. J. Pharm. Dev. Ind. Pharm. 1(2): 15-20.

Obidike, IJ; Egbuonu, AC (2020). Some biochemical effect of cocoa (Theobroma cacao) pod ethanol extract on renal histo-morphology and function in monosodium glutamate (MSG)-intoxicated rats. Int. J. Recent Res. App. Studies. 7,5(3): 17-28.

Ochei, J; Kolhatkar, A (2008). Medical Laboratory Science: Theory and Practice. Tata McGraw Hill Publishing Co. Ltd., New York, USA. Pp 311-347.

Ogundare, AO (2011). Antibacterial properties of the leaf extracts of Vernonia amygdalina, Ocimum gratissimum, Corchorous olitorius and Manihot palmate. J. Microbiol. Antimicrobials. 3(4): 77-86.

Okpoghono, J; Achuba, FI; George, BO (2018). Protective effect of Monodora myristica extracts on crude petroleum oil contaminated catfish (Clarias gariepinus) diet in rats. Int. J. Vet. Sci. Med. 6:117-122.

Oyedeji, KO; Bolarinwa, AF (2013). Effect of metronidazole on haematological parameters in male albino rats. IOSR J. Dental Med. Sci. (IOSRJDMS). 3(5): 61-63.
Ugwuene, MC (2011). Effect of dietary palm kernel meal for maize on the haematological and serum chemistry of broiler Turkey. Nig. J. Animal Sci. 13: 93-103.

Veni, NK; Karthika, D; Surya, DM; Rubini MF; Vishalini, M; Pradeepa, YJ. (2010). Analysis of monosodium 1-glutamate in food product by high performance thin layer chromatography. J. Young Pharm. 2(3): 297-300.

Wijayasekara, K; Wansapala, J (2017). Uses, effects and properties of monosodium glutamate (MSG) on food \& nutrition. Int. J. Fd. Sci. Nutr. 2(3): 132143.

Zeratsky, K (2020). Answer to the question: Nutrition and healthy eating: monosodium glutamate: is it harmful? Available

(a): https://www.mayoclinic.org/healthylifestyle/nutrition-and-healthy-eating/expertanswers/monosodium-glutamate/faq-20058196. Accessed on 06 February, 2021.

Zubairu, AY; Mukhtar, M; Saidu, I; Ibrahim, Z; Isah, S; Garga, MA; Kebbi, HS (2019). Antibacterial activity of methanolic extract of bitter leaf (Vernonia amygdalina) from various component fractions using column chromatography. GSC Biol. Pharm. Sci. 2: 16-21. 